\title{
Lay and Professional Judges in Europe's Labour Courts: Does the Professional Judge Dominate?
}

SUSAN CORBY*, PETE BURGESS ${ }^{\star *}$, ARMIN HÖLAND***,. HÉLÈNE MICHEL ${ }^{* * * *}$, LAURENT WILLEMEZ *****

\section{ABSTRACT}

Several European countries have a first instance 'mixed' labour court, that is a judicial panel comprising a professional judge and two or more lay judges, the latter with experience as employees or employers/managers. The lay judges' main contribution is their workplace knowledge, but they act in a juridical setting where legal norms prevail, so does the professional judge, despite being in a minority, dominate? This article seeks to address this question by focusing on first instance labour courts in Great Britain, Germany and France.

Theories of differential power, particularly status characteristics theory, and previous empirical research indicate that professional judges dominate, but our findings are more nuanced. Based on 177 interviews in three countries, we find that professional judge dominance varies according to the country's institutional context and the salience of lay judges' workplace knowledge. These institutional differences, however, are mediated by the attitudes of the judicial actors. Many interviewees noted that some lay judges were more prepared to challenge the professional judge than others, while others observed that some professional judges were more inclusive than others.

\footnotetext{
*University of Greenwich

**University of Greenwich

*** Zentrum für Sozialforschung,
} 


\section{**** Université de Strasbourg \\ ***** Université de Versailles}

The authors thank Professor Patricia Leighton, Dr Maureen Spencer and Professor Paul Latreille for their comments on an earlier draft, although interpretation and any errors are the authors. The authors also thank the Hans-Böckler-Stiftung for the funding of the research from which this article stems.

Keywords: employment tribunals, labour courts, judges, lay judges, status characteristics

\section{INTRODUCTION}

The decrease in trade union membership and the increase in individual employment rights in western Europe since the 1980s have led to a process of juridification, that is increasing legal intervention in the employment relationship and consequently a significant role for the courts in resolving employment disputes. Such courts are either general civil courts or specific labour courts Several European countries have first instance labour courts whose judgments are either always, or sometimes, reached by a so-called 'mixed' panel, that is a panel containing a professional judge and lay judges. ${ }^{1}$ The latter are drawn from the working population with experience as either employees or employers/managers; they are thus familiar with workplace norms and are not required to have any legal expertise, unlike the professional judge who will have had legal training.

This paper deals with first instance labour courts in Great Britain, France and Germany and focuses on the relationship and interactions between the lay judges and professional judges with their different backgrounds and norms. The research was conducted as part of a wider study funded by the Hans Böckler Foundation. ${ }^{2}$ Our research question here is: given that the vast majority of judgments are reached unanimously, ${ }^{3}$ does the professional judge dominate? 'Dominant' is defined

\footnotetext{
${ }^{1}$ European countries with mixed labour courts (i.e. professional and lay judges) include Austria, Belgium, Denmark, Finland, France, Germany, Great Britain, Luxembourg, Slovenia, and Sweden.,

2 P. Burgess, S. Corby, A. Höland,, H. Michel, L. Willemez, L., C. Buchwald. And E. Krausbeck. 'The Roles, Resources and Competencies of employee Lay Judges: a cross-national study of Germany, France and Great Britain, Working Paper 151, (Dusseldorf: Hans Böckler Stiftung 2017).

${ }^{3}$ See, for instance for Britain, Painter, R. and Holmes, A. Cases \& Materials on Employment Law, $7^{\text {th }}$ edn, (Oxford: Oxford University Press , 2008) and for Germany Höland, A. 'Ehrenamtliche Richterinnen und Richter in der Arbeitsgerichtsbarkeit - Laienspieler oder rechtsstaatliche Qualitätssicherung' in Dieterich, T., Le Friant, M., Nogler, Kezuka, K. and Pfarr, H., Individuelle und kollektive Freiheit im Arbeitsrecht Festschrift für Ulrich Zachert. (BadenBaden: Nomos Verlag, 2010).
} 
as 'ruling, prevailing, most influential'4 and does not necessarily occur because the professional judge suppresses dissent. It may occur because lay judges defer.

The labour courts in these countries are called employment tribunals in Great Britain, Arbeitsgerichte in Germany and conseils de prud'hommes in France, but we use the generic term 'labour court' in this paper. We also use the generic words 'lay judge': the local designations are lay member in Great Britain, ehrenamtliche Richter in Germany and conseiller in France. And we use the term 'professional judge', known as the employment judge in Great Britain, Berufsrichter in Germany and juge départiteur in France.

Theories of differential power in decision-making contexts, particularly status characteristics theory, together with previous empirical research, indicate that professional judges are dominant. Our findings are more nuanced, however. We find that such dominance is conditioned by the institutional context of the country concerned, particularly the salience of lay judges' workplace knowledge in the adjudication process. This institutional context, however, is mediated by the attitudes of the lay and professional judges.

The plan of this paper is as follows. First, we outline the national contexts and then look at theories of differential power and previous empirical research on mixed courts. Next after sketching our methodology, we examine our findings, distinguishing between the hearing and the ensuing deliberations and considering the attitudes of the lay and professional judges. Finally, we return to our research question and conclude with some observations.

\section{BACKGROUND 5}

Labour courts in France, which have a long history compared to those in Germany and Great Britain, were created in the $19^{\text {th }}$ century as a forum for bringing workers and employers together to settle disputes without the involvement of professional judges. After a series of reforms, today all cases

\footnotetext{
${ }^{4}$ The Concise Oxford Dictionary
}

${ }^{5}$ This section of the article draws from the research study; see note 2. 
are heard by two employee lay judges and two employer lay judges, with one of the lay judges in the chair. Only if there is no agreement, which occurs in a fifth of cases, ${ }^{6}$ is there a rehearing; normally this involves the four original lay judges together with a professional judge, who acts as tie-breaker. An appeal on fact (but only if the amount in dispute is over $€ 4,000$ ) and law goes to the social chamber of the Court of Appeal and on law only to the Supreme Court.

German labour courts have existed in their current form since the Weimar Republic. They cover both collective and individual disputes in the public and private sectors, except those concerning established civil servants (Beamte) and are tripartite: a professional judge with two lay judges (employer/employee). Unlike France and Great Britain, Germany has a separate strand of tripartite labour jurisdiction, with appeals from $1^{\text {st }}$ instance decisions on fact and law going to the Land labour court and then on law only to the Federal Labour Court.,

British labour courts, which originated in the 1960s to hear appeals against training levies, soon began to hear party $v$ party employment disputes. Appeals on law only are determined by a specialist labour court (the Employment Appeal Tribunal) and then go to generalist appellate bodies (the Court of Appeal and the Supreme Court). There is a strict doctrine of precedent in Great Britain, unlike in the two civil law countries (France and Germany), although this difference is more apparent than real as judgments of the superior courts guide the German and French lower courts. Uniquely, however, there is cross-examination in British $1^{\text {st }}$ instance labour courts, so cases often last several days (especially dismissal and discrimination cases), whereas in France and Germany several cases can be heard in half a day as the focus is the parties' submissions, with the presiding judge seeking clarification if necessary.

In Germany, virtually all cases are heard by a mixed labour court, that is an employee lay judge, an employer lay judge and a professional judge. In Great Britain, only some cases are heard by a mixed labour court; the professional judge alone determines a vast range of cases including

\footnotetext{
${ }^{6}$ Ministère de la Justice Activitité des conseils de prud'hommes. (2016) http://www.justice.gouv.fr/statistiques10054/references-statistiques-justice-12837/activite-des-juridictions-donnees-2016-31194.html [accessed 25.7.18]
} 
redundancy payments, holiday pay and importantly discrete unfair dismissal cases. Although the professional judge can exercise their discretion and depart from this default position of sitting alone in certain prescribed circumstances, in practice lay judges almost always only sit on discrimination cases, which may or may not also include other concurrent claims such as an unfair dismissal claim. ${ }^{7}$ As Dickens has noted, this represents a significant move away from tripartism, which is the norm in the enforcement of employment rights in Europe. ${ }^{8}$

Where there is a mixed first instance labour court, the professional judge chairs the hearing ${ }^{9}$, chairs the deliberations and writes the judgment. Nevertheless, both in Germany and Great Britain the two lay judges and the professional judge have an equal vote, so there is a tension, at least theoretically, between the enhanced role of the professional judge and equality between all three judges as the two lay judges can outvote the professional judge. In fact, they rarely do so. ${ }^{10}$ Is this because of professional judge dominance?

Lay judges in all three countries take up their role through nationally distinctive routes. In Germany, employee lay judges are nominated by trade unions (or other independent associations of employees) and employer lay judges by employers' associations. Nominations are lodged with the Land (regional) authorities, but the latter do not merely rubber stamp the nominating bodies' lists as they have an obligation to ensure that there is an appropriate balance of minorities, referring to smaller trade unions/organisations rather than demographic categories. ${ }^{11}$ In France, until 2018 employee lay judges were elected by employees, essentially on the basis of lists drawn up by the trade unions, while employer lay judges have been elected by employers on the basis of lists drawn

\footnotetext{
${ }^{7}$ British lay judges are also required to sit on cases where a whistle-blower claims to have suffered a detriment.

${ }^{8}$ L. Dickens, 'The coalition Government's Reforms to Employment Tribunals and Statutory Employment Rights - Echoes of the Past' (2014) 45(3) Industrial Relations Journal 234-249.

${ }^{9}$ Germany: Civil Code of Procedure; Great Britain: Employment Tribunals (Constitution and Rules of Procedure) Regs 2013

${ }^{10}$ See note 3.

${ }^{11} \mathrm{P}$. Bader, R. Hohman. and H. Klein, Die ehrenamtlichen Richterinnen und Richter in der Arbeits - und Sozialgerichtsbarkeit, 13 ${ }^{\text {th }}$ edn, (Heidelberg: C. F. Müller Verlag 2012) 47.
} 
up by employers' associations. Now however, French lay judges are nominated by employers' associations and trade unions in a procedure akin to the German model.

In Great Britain, in a process overseen by the Judicial Appointments Commission, there are advertisements, in response to which applicants self-nominate and complete an extensive application form including details of their work Those meeting a person and job specification are then selected for interview, and if successful denote whether they wish to sit as an employee or employer lay judge. Importantly, those with experience as employees may not even be union members. Of our 41 employee lay judge interviewees, only 14 were union members at the time of the interview.

Professional labour court judges also take up their role through nationally distinctive routes. Professional judges in Great Britain, unlike their German and French counterparts, are not required to have studied law as a university undergraduate; a legal qualification can be obtained subsequently. They are, however, required to have practised in a legal activity for at least five years before being appointed and normally labour court professional judges have had extensive employment law experience. ${ }^{12}$ In France there is a career judiciary. Professional judges, after obtaining a University law degree, attend the National School for the Judiciary, and then are assigned to a court, changing jobs every few years both in respect of location and type of court. Thus, they are not experts in labour law, a situation exacerbated by the fact that labour law instruction at university is declining and professional judges are usually district judges who spend only a minority of their time in the labour court. In Germany too, as in France, there is a career judiciary but German professional judges, when assigned to the labour court, are there full-time for several years. Table 1 captures some key differences.

Table 1 to be inserted about here.

\section{THEORIES OF DIFFERENTIAL POWER}

12 On 1.4.17, 112 professional judges had a background as barristers, 209 as solicitors with one unknown and two not declaring according to the Ministry of Justice Judicial Diversity Statistics 2017. 
Having sketched the institutional provisions, we now turn to theories of differential power relations in decision-making contexts, first in the juridical field and then more generally. Bourdieu ${ }^{13}$, in his classic treatment of the juridical field, submits that the field is organised around a body of internal protocols, behaviours, rules, values and a sophisticated body of knowledge, over which those who possess legal qualifications have mastery because of their possession of specific capital, 'legal capital'. Accordingly, it is the view of the legal professional that prevails and:

... often runs contrary to the simple counsels of common sense, entails the disqualification of the nonspecialists' sense of fairness and the revocation of their naïve understanding of the facts, of their 'view of the case'. ${ }^{14}$

Thus, juridical norms legitimise 'victories over the dominated' (that is lay people) and because they 'partake both of the positive logic of science and the normative logic of morality' they are 'capable of universal acceptance'. ${ }^{15}$

In Bourdieu's schema, however, where are lay judges situated? Francis, drawing on Bourdieu, considers quasi-lawyers, such as legal executives and law students whom he says are on the edge of law, but he does not discuss the position of lay judges. ${ }^{16}$ In particular, are French labour courts, where professional judges rarely sit, inside or outside Bourdieu's juridical field? Furthermore, is the lay/legal dichotomy an unwarranted simplification? Newman argues that it is. ${ }^{17}$ She submits that both workers and employers accept certain legal concepts and ways of thinking which are applied, for instance, in disciplinary proceedings in the workplace, so law and industrial relations norms interpenetrate.

\footnotetext{
${ }^{13}$ P. Bourdieu, 'The Force of Law: Towards a Sociology of the Juridical Field' (1987) 38 The Hastings Law Journal 814-853.

14 Ibid.. 828

15 Ibid 818.

${ }^{16}$ A. Francis, At the Edge of Law: Emergent and divergent Models of Legal Professionals, (Farnham: Ashgate 2011).

${ }^{17}$ R. Newman, 'Laymen as Lawyers in the Processing of Dismissal Disputes' (1987) 14(2) Journal of Law \& Society 217228.
} 
Accordingly, we draw on another theoretical framework on differential power in decision making, status characteristics theory, which stems from a different discipline, social psychology. Status characteristics theory was developed in a series of research studies starting with Berger et al. ${ }^{18}$ to explain interactions in small task groups within organisations. These interactions, they said, are shaped by how group members perceive each other's status and they distinguish 'diffuse' status characteristics from 'specific' status characteristics. Diffuse status characteristics include gender, ethnicity, age and social class and are indirectly related to the immediate task. Specific status characteristics, in contrast, are directly related to the immediate task and include task relevant education, training and experience with similar tasks.

Specific status characteristics are more salient than diffuse ones and may over-ride, or reinforce, diffuse characteristics. Typically, specific status characteristics, such as experience and expertise, are distributed differentially within task groups and so some group members are almost invariably less expert in the performance of a particular task than others. This results in status characteristics affecting group members' estimations of the performance capacities of themselves and others in the group and behaviour follows in accordance with those expectations. A group member for whom others' expectations are relatively high will have a higher status and thus more power and will initiate more interaction, receive more attention and deference, and exercise greater influence in the group, especially when there are disagreements. At the same time, low status group members will expect more valuable contributions from the high status group member and, in exchanging views about a task, will be influenced by the opinions of the high status group member on the assumption that doing so will help the group as a whole to accomplish the group's goals Thus status is not merely a descriptor; it determines interaction and the observable power and prestige order in groups. (See also Wagner and Berger; Webster Jnr and Hysom; and Bunderson. ${ }^{19}$ ) We will

\footnotetext{
18 J. Berger, B. Cohen, B. M. and Jr Zelditch, 'Status characteristics and Social Interactions' (1972) 37(3) American Sociological Review 241-255.

${ }^{19}$ D. Wagner and J. Berger, J. 'Status characteristics Theory: The Growth of a Program' in J. Berger and M. Zelditch (eds), Theoretical Research Programs: Studies in Theory Growth (Stanford Ca: Stanford University Press 1993). M. Jr Webster, and S. Hysom 'Creating Status Characteristics' (1998) 63(3) American Sociological Review 351. S. Bunderson,
} 
revisit status characteristics theory in the light of our findings, but first we briefly review previous relevant empirical research.

\section{EMPIRICAL RESEARCH ON 'MIXED’ COURTS}

Empirical research on mixed courts in several countries on the role of the professional judge vis-àvis the lay judges has concluded that the professional judge is dominant.

For instance, Kutnjak Ivkovic ${ }^{20}$ looked at criminal courts in Croatia, explicitly applying status characteristics theory. Using data obtained from questionnaires, she found that lay judges, because of their lack of legal training/experience, were seen by their fellow lay judges and the professionals as less competent than the professional judges. Lay judges made fewer comments than the professional judge in deliberations and any comments or contributions they made received a less favourable reaction from other lay and professional judges. In short, she found that because the task was to come to a judgment taking account of the law and legal norms, professional judges had a higher status than lay judges and dominated deliberations.

Machura examined interactions between lay and professional judges in German criminal courts. ${ }^{21} \mathrm{He}$ found that lay judges remained silent during a trial, largely because of their lack of information about the case. He also found that although the lay and professional judges had the same formal decision-making rights, the procedural rules gave the professional judge a dominant position. In addition, Machura carried out studies of mixed criminal courts in southern Russia and administrative courts in Germany. ${ }^{22}$ His conclusions in all these studies were that in interactions between lay and professional judges, the latter dominated. Furthermore, Machura found that lay

\footnotetext{
'Recognizing and Utilizing Expertise in Work Groups: A Status Characteristics Perspective' (2003) 48 Administrative
} Science Quarterly 557-591.

${ }^{20}$ S. Kutnjak Ivkovic, 'Lay Participation in Decision Making: A Croatian Perspective on Mixed Tribunals' (1997) 36(4) The Howard Journal 406-423. S. Kutnjak Ivkovic 'Exploring Lay Participation in Legal decision Making': Lessons from Mixed Tribunals' (2007) 40 Cornell International Law Journal 429-453.

${ }^{21}$ S. Machura 'Interactions between Lay Assessors and Professional Judges in German Mixed Courts' (2001) 72 International Review of Penal Law 451-477.

22 S. Machura, 'Fairness, Justice and Legitimacy: experiences of People's Judges in South Russia' (2003) 25(2) Law \& Policy 123-150. S. Machura, 'Lay Assessors of German Administrative Courts: Fairness, Power-distance Orientation and Deliberation Activity' (2007) 4(2) Journal of Empirical Legal Studies 331-363. 
judges deferred more to the professional judge in former East Germany than in former West Germany and that in southern Russia lay judges were seen as passive and often termed 'nodders'.

Nevertheless, there are some qualifications. Machura found in all these studies that lay judges were more active in deliberations where the professional judge treated them as equal partners and where the lay judges perceived that the professional judge was fair. Fujita and Hotta, using mock juries and fictitious criminal scenarios, stressed the importance of information and found that lay participants in decision making could be hampered because of their informational disadvantage. ${ }^{23}$ The extent to which these studies of criminal courts read across to labour courts is questionable, however. For instance, in German criminal courts the professional judge is inhibited from passing on case information to the lay judges to preserve their veil of innocence, but in the German labour court the professional judge will brief the lay judges on the case.

In the studies cited above, the lay judges are representative of the population in general and are not required to have any particular expertise, unlike lay judges in labour courts who are required to have workplace experience. Nevertheless, studies of the relationship between professional judges and lay judges have also found professional judge domination in labour courts. Thus Dickens et al. ${ }^{24}$ study argued that 'various factors' made the professional judge 'first among equals' and that the professional judge's status, greater experience and legal knowledge 'can be expected to have some effect on the process of decision making'.

Focussing on French labour courts, Willemez ${ }^{25}$ found that many French lay judges (who as noted above make decisions without a professional judge), 'had a strong sense of being illegitimate' compared to the legally qualified. As to German labour courts, Brandstätter et al. ${ }^{26}$ found that lay judges perceived professional judges as dominating deliberations because of their expertise and

\footnotetext{
${ }^{23}$ M. Fujita and S. Hotta, 'The impact of differential information between lay participants and professional judges on deliberative decision-making' (2010) 38 International Journal of Law, Crime and Justice, 216-235.

${ }^{24}$ L. Dickens, M. Jones, B. Weekes and M. Hart, Dismissed: A Study of Unfair Dismissal and the Industrial Tribunal System, (Oxford: Blackwell, 1985), Ch. 3.

${ }^{25}$ L. Willemez, 'French Labor Tribunals and the Making of Labor Law: Towards a Sociology of Judicial Roles' (2013) 55 Sociologie du Travail, 83.

${ }^{26} \mathrm{H}$. Brandstätter, L. Bleckwenn and G. Kette, 'Decision-making of industrial tribunals as described by professional and lay judges' (1984) 33(1) International Review of Applied Psychology, 154.
} 
professional judges 'stated unequivocally that [lay judges] were in fact not [their] equal partners in decision-making'.

Most of the empirical research outlined above does not relate to labour courts and where it does, is rather dated. Against that background, we now turn to our research and consider the relationship between professional judges and lay judges in German, French and British labour courts today.

\section{THE RESEARCH METHODOLOGY}

Primary data collection was through interviews as the objective was to elicit the complexity and richness of the perceptions of those interviewed. In addition, even if we had wanted to conduct a large-scale quantitative survey this would not have been practicable as it was not possible to compile a probabilistic random sample of lay and professional judges in each country due to problems of access. We also chose not to base the research on observation of hearings as this would not capture the relations between the judges during adjournments and deliberations. Nor was data collected through observation of deliberations. Indeed, we did not seek such permission, bearing in mind that such permission would be refused given the confidentiality of deliberations and the fact that, even if permission were granted, the presence of an observer could alter the dynamics and interactions.

Interview guides, with questions and prompts, were drafted and redrafted by the researchers in the light of the literature review, first in English and then translated into German and French and localised. They were then piloted to ensure reliability, after which semi-structured interviews were conducted in four or five locations in each of the three countries: 147 with lay judges and 30 with professional judges ${ }^{27}$, with all the interviewees self-selecting. ${ }^{28}$ Although this creates the scope for

\footnotetext{
${ }^{27}$ There are no full-time professional judges in French labour courts, so only five professional judges were interviewed in the chosen locations in France, compared to 13 in Germany and 12 in Great Britain.

${ }^{28}$ In Great Britain, following judicial approval, invitations were sent out by the relevant regional employment judges/Scottish vice-president. In Germany judges were contacted by the relevant labour courts, while in France a snowball process was adopted after first interviewing the president or vice-president of the labour court.
} 
bias, this seems to have been limited as there was a variety of views on certain issues and there were opportunities for triangulation with other interviews.

Interviews, which lasted on average an hour, were transcribed and analysed in three stages. First, themes were initially identified both from the interview guides and the interviews themselves. Secondly, these themes were refined and finally the primary data was revisited by reading entire transcripts yet again. This led to a common coding system being developed using MaxQDA. To ensure inter-coder reliability, coded transcripts were exchanged and cross-checked. There was some quantizing in reporting findings to emphasise the frequency of particular responses, using terms such as 'many', 'few', indicating the main features of a sample, but without claiming precision.

The primary data collection method was supplemented by desk research on national institutions, labour court procedures and industrial relations provisions, by a few interviews with experts and some observations of labour court hearings in each researcher's own and other countries to better understand the context.

In the quotes from interviewees, countries are denoted by GB (Great Britain), G (Germany) and $F$ (France). In Germany only, court locations have been indicated. The German abbreviations are $\mathrm{DO}=$ Dortmund; $\mathrm{MA}=$ Mannheim; $\mathrm{HAL}=$ Halle; and $\mathrm{B}=$ Berlin. EE refers to an employee lay judge; ER to an employer lay judge; and PJ to a professional judge.

As noted above, we focus here on one element of this study, the relationship and interactions between the lay and professional judges and consider whether lay judges are dominated by the professional judge. We look in turn at the information available to the judges before the hearing, the hearing itself, deliberations and the perceptions of lay and professional judges about their relationship.

\section{FINDINGS}

\section{A. Informational advantage}

It is a truism that information is power, so a person who has more information than others is more likely to be able to dominate those others. Furthermore, previous research on courts has noted that 
lay judges who have less information than the professional judge are disadvantaged, ${ }^{29}$ so do professional judges have an informational advantage vis-à-vis the lay judges even before the hearing begins?

We first deal with legal knowledge. Of course, all professional judges have legal knowledge, but this should be qualified. British and German professional judges have a high level of knowledge of employment law. Moreover, most British and German professional judges sit virtually full-time in the labour court, enabling them to rapidly amass experience and expertise. In contrast French professional judges have often not studied employment law and normally sit in the District Court, only occasionally sitting in the labour court at most once or twice a week, as noted above.

As to the lay judges, our research found that in Germany lay judges sit 4-6 days a year and in Great Britain there is a wide range of 0 to over 20 days, so many acquire judicial experience slowly. In France, the position varies. Some lay judges, such as those who are presidents (chairs) of chambers, sit several times a week. Moreover, in contrast to their British and German counterparts, French lay judges need to have knowledge of employment law, because, as noted, they mostly sit without a professional judge and one of the panel of four lay judges is responsible for writing the judgment, albeit with the assistance of the legally-qualified court clerk, the greffier. As a French lay judge said:

I learned to read the law. Reading the law is very complicated, knowing that a comma, if placed before or after the word, can change the meaning. One section will tell you something, but this can be contradicted or possibly interpreted in one way or another. (F EE 10).

In this context, it is perhaps not surprising that French lay judges are entitled to receive much more training than their British and German counterparts. In France, lay judges are entitled to receive six weeks of training during their five-year period of office and such training is variously provided, for instance by trade unions, employers' associations, and educational institutions to their

\footnotetext{
${ }^{29}$ See note 23.
} 
'own' lay judges. Moreover, in future under a new law there will also be state-provided training of employee and employer lay judges jointly at l'Ecole Nationale de la Magistrature.

In Great Britain, lay judges have been required to have had training before they sit and to receive one day's training each year (two days in Scotland) covering both employment law and judgecraft. There is no such state-provided training provision for lay labour court judges in Germany, although some courts, some trade unions and some employers' associations offer training and lay judges who have been/are works councillors will have been exposed to employment law issues.

As to whether professional judges have an informational advantage in respect of the instant case, the short answer is 'yes' in Germany, 'no' in Great Britain and 'to some extent' in France. German professional judges will have worked on the case papers for some weeks and will have conducted a conciliation hearing with the parties (and/or their representatives) without the presence of the lay judges and so will have already got to grips with the parties' main arguments. If conciliation is not successful, the same presiding judge will normally chair the merits hearing. For their part, German lay judges usually only have access to the case papers for the scheduled hearing on the day of the hearing itself and however much effort the lay judges might invest in reading the files, it is virtually impossible for them to catch up with the professional judge's familiarity with the case.

In contrast, in Great Britain conciliation is carried out by a separate body, the Advisory Conciliation and Arbitration Service (Acas), and there is no formal or informal communication between the conciliation officer and the professional judge. Furthermore, if exceptionally there is judicial mediation or a judicial assessment, any subsequent merits hearing is chaired by a different professional judge. Moreover, when a claim is submitted to a British labour court a professional judge normally conducts a preliminary hearing, which at the very least includes contacting the parties to clarify the issues and determine the days to be allocated for a hearing, but a different professional judge will usually conduct the main (merits) hearing and will not have seen the file until often less than an hour before the lay judges or somewhat cursorily the evening before. If there is a large amount of documentary evidence in respect of the case to be adjudicated, this is generally delivered at the last minute. Normally, therefore, after the formal opening of the hearing, there will be 
an adjournment so that the documents can be read, with the lay judges and the professional judge reading together. This engenders collegiality and relationship building.

In France, the position is less clear cut. On the one hand, the lay judges who attend the tiebreak hearing will have heard the case originally and, indeed, two of those lay judges will often have attempted to conciliate before any hearing. On the other hand, the French professional judges will have read the case files beforehand.

\section{B. The lay judge role in hearings}

An observer of a labour court hearing in all three countries is very likely to conclude that the professional judge dominates as the procedural rules of the court require him/her to be in the chair. This is enhanced in Germany and France because professional judges are distinguished from their lay judges by their dress; professional judges wear a robe. There are no such dress distinctions between the judges in Great Britain.

Largely because there is cross-examination in British courts, unlike France and Germany, hearings in British mixed labour courts often last for several days; see above. ${ }^{30}$ These longer British hearings allow more opportunities for relationship building and interaction between the lay and professional judges than occurs in Germany or France. For instance, in Great Britain, there are adjournments for lunch and at the end of the day of a multi-day case, when the panel takes stock and exchanges views. Also, several British lay judges commented that they could, and often did, pass a note to the professional judge requesting a short adjournment at other times of the day. This may have been prompted by an event in the court room or the behaviour of a witness or the professional judge. 'Two or three little chats along the way' (GB PJ 8) according to a professional judge. Moreover, a lay judge said one professional judge at the end of the day would:

\footnotetext{
${ }^{30}$ The British professional judge sits alone on cases that are normally simpler and therefore have shorter hearings, such as holiday pay, deductions from wages, redundancy pay and unfair dismissal. The longer cases typically involve discrimination for which lay judges are required and some British lay judge interviewees reported that they had adjudicated in cases lasting $\mathbf{2 0}$ days or more.
} 
... produce a little précis of the evidence ... and he sends those by email to us both so that when we come in the next morning we can either agree with him or disagree with him. Sometimes we do disagree (GB EE 10).

Interestingly, it was reported that there was occasional 'backroom' cooperation between the professional and lay judges in respect of questioning in open court. A British lay judge said: 'If I say, "well I'm thinking of asking this" and the [professional] judge will say "yes, I was thinking of doing that", then you might say "well who might be best to do it"' (GB EE 39). German judges also reported adjournments, for instance to exchange views and to co-operate in respect of questioning, but they had less opportunity to do so because of the shorter hearings.

Importantly, we found that British lay judges were more involved in the hearing than their German counterparts because of their responsibility for systematic note-taking. This is because there is no recording technology in the court-room, yet the professional judge is obliged to make a full note of what is said at the hearing as this could be required for an appeal. As a lay judge said:

They [professional judges] say that they rely on us, especially when they're asking questions, because when they're asking questions they're looking at the parties and not writing things down (GB EE 6).

British professional judges, we were told, would also confirm their notes with lay judges: 'Quite often, if you break for lunch or at the end of the day, the [professional] judge will say, "I've got this noted, is that your understanding?"' (GB ER 1). Moreover, British lay judges' notes can be decisive in the event of a complaint of bias, endowing lay judges with some latent power. ${ }^{31}$ 'We often say to the [professional] judges "Oh, you're lucky to have us" in the event of some sort of argy-bargy' (GB EE 38).

In Germany, in contrast, there was little or no note-taking. Professional judges use hand-held devices to record key aspects and decisions, but this is not a record of the proceedings, although in

${ }^{31}$ We were told that volume of complaints in respect of professional judge bias had increased significantly in the last few years. Our informant speculated that this may be because of a growing culture of customer complaints and/or a result of the fees regime between 2013 and 2017 where a claimant did not want to lodge an appeal on judicial bias because of the cost and so instead opted for a cheaper route - a complaint of bias. 
some courts, such as Berlin, there is a minute-taker. In France, the presiding lay judge, although not legally required to make verbatim notes, will take notes as he/she later has the responsibility of writing the judgment; in addition, a court clerk also normally takes some notes.

In all three countries the lay judges reported that they closely observed the demeanour of those putting forward their case. In Great Britain, the lay judges regarded this as especially important because the professional judges have their 'head down and writing almost all the time. They don't look at the court room' (GB EE 5). Another British lay judge said: 'Some of [the professional judges] do recognise that and say: "please be my eyes"' (GB ER 6).

\section{The lay judge role in deliberations}

Turning from the hearing to deliberations, a British professional judge, in a comment in a judgment said:

We emphasise that we are a tribunal panel of three individuals. Each of us has a say in the judgments we reach; the fact I as the [professional] judge, have done most of the talking for the panel [at the hearing] does not mean that I have done most of the deciding. ${ }^{32}$

These sentiments were echoed by German professional judge interviewees.

In deliberations in both countries, however, the professional judge leads the discussion, often starting by asking the lay judges for their views or sometimes by giving a preliminary view, but the lay judges interviewed did not report that they felt that they were dominated by the professional judge.

A German lay judge described it as being 'a path that you travel along together' (G EE HAL 11) and almost half of British lay judges used the words 'collegiate' or 'team' when talking about the tenor of deliberations. In France in contrast where there is a mixed tribunal, the professional judge is the tie-breaker, inevitably a position of dominance.

\footnotetext{
32 Fairbairn v Priory Project Ltd, (2015) 1601150/2014 unreported, para. 13.
} 
Irrespective of the deliberative process, all the lay and professional judges interviewed, when asked to pinpoint the most important contribution of lay judges to the deliberations and judgment, most frequently mentioned workplace experience. The reasonableness of the employer's behaviour, and thus knowledge of workplace norms, is often a key consideration in reaching a judgment in a contested dismissal case, whereas workplace norms are largely irrelevant in discrimination. As noted above, however, British lay judges do not normally sit on discrete unfair dismissal claims; in the main they only adjudicate a claim of unfair dismissal where there is a concurrent discrimination claim. Moreover, where they do, they have been enjoined by the superior courts not to substitute their judgment for that of the employer, in other words not to put themselves in the employer's shoes, but merely to review the employer's actions within a broad band. ${ }^{33}$ There is no such restriction in France and Germany: the judges make their own independent assessment of whether or not the employer acted reasonably.

Also, there is some attempt to match French and German lay judges' workplace experience with the claimant's workplace. In France, lay judges are allocated to one of five (admittedly broad) chambers in the labour court: industry, commerce, miscellaneous activities ${ }^{34}$, agriculture and supervision/management (cadres). In Germany, in the larger cities (such as Berlin and Frankfurt) the labour court is divided into chambers (Fachkammern) for a specific sector which has distinctive features such as construction, or seafarers, or the public sector. In marked contrast, the British appellate court has said that British lay judges should not be selected to sit on a hearing because of the specialist knowledge they may hold, as this prior knowledge might prevent them from looking solely at the evidence presented to them. ${ }^{35}$

The salience of German and French lay judges' workplace knowledge is heightened by the fact that German and French professional judges almost always lack workplace knowledge because they

\footnotetext{
33 Secretary of State v Lown [2016] IRLR 22; Anglian Home Improvements v Kelly [2004] IRLR 793; British Home Stores v Burchell [1978] IRLR 379.

${ }^{34}$ Service industries that do not come under the heading of commerce are included in this category.

${ }^{35}$ Halford v Sharples \& Ors [1992] ICR 146. This is similar to the doctrine of the cognitive innocence of lay judges in German criminal courts.
} 
are career judges as noted above. British professional judges will normally have had experience as employment lawyers and thus have knowledge of workplaces in many a sector, albeit indirectly through those they have represented, while many of the British lay judges we interviewed only had had experience in one sub-sector.

Unsurprisingly given the institutional context, German lay judges referred to the importance of their workplace knowledge and experience. As an interviewee said: 'the most important thing ... is the experience of life that l've had in very different sorts of work' (G EE B 53). To give further examples, another interviewee said: 'I can be a lot of help to the [professional] judge where the case involves my branch' (G EE MA 61). Yet another said: 'There are always just aspects that I can cite from my workplace experience, but which can lead to a judgment going in a different direction' (G ER DO 45). Still another said that lay judges understood 'local economic, labour market and social issues and developments' and could therefore bring those issues into [the court] (G ER DO 41); bring 'a perspective from practice because it's not always easy for the [professional] judge if they are only in court' (G EE HAL 12).

The German professional judges also valued the workplace experience of the lay judges as their comments indicate. 'l'd ask the lay judge "How do you see that... Is that grounds for summary dismissal?"' (G PJ B 8). 'You can see the [lay judges] think about how a case might look if it happened in their own firm' (G PJ MA 65). Moreover, German professional judges readily admitted that they lacked workplace knowledge. 'Of necessity, my experiences of working life are limited and I can draw on the experiences of the lay judges (G PJ MA 54). 'There are many details of workplace practice that the professional judge doesn't have and that can be made up for by the lay judges' (G PJ HAL 23). 'They can tell us about technical matters, work preparation, the jobs; and employer representatives often have knowledge about personnel issues' (G PJ DO 35). 'There are [employee lay judges] who are foremen or just normal construction workers. They'll have something to add if we have a case, especially if it turns on the employee's behaviour' (G PJ B 36).

In France too, all the lay judges interviewed said that they drew on their workplace experience both generally and specifically and this was valued by the French professional judges. As a 
professional judge said: 'These [lay judges] know the workplace ... better than a lawyer who's correct in his field but who is not familiar with workplace life and the concrete problems that can come up in the workplace.' (F PJ 19).

Turning to Great Britain, although virtually all the British professional judges whom we interviewed gave an instance of when a lay judge deployed his/her workplace experience in deliberations about a case and persuaded them to change their mind about an issue, they said this was just one instance in many years and did not necessarily change the outcome. Moreover, one British professional judge said that British lay judges' knowledge of the workplace 'was quite low down on the list' (GB PJ 3). Almost all the professional judges interviewed, however, commented that lay judges' workplace experience was principally useful in contested dismissal cases and lamented the fact that normally they were confined to discrimination cases, while another professional judge said:

$50 \%$ of [lay judges] don't really understand the difficult legal concepts [in discrimination cases] They'll say 'look, I don't understand. I'm happy to go with you. I trust you; you tell me; you spell it out for me and I'll tick the box almost'. So we don't have them in the unfair dismissal regime where their usefulness was most appropriate (GB PJ 1).

Many lay judges agreed that they were less useful in discrimination claims than in contested dismissals. For instance, one said, 'Lately, I think one's contribution is somewhat limited given the way the law's moved... and the ability to make a difference has gone' (GB EE 11), while another said: 'Because discrimination is so legally bound and ever-changing and complex, the [professional] judges really lead.... So, you know, you feel less empowered, if you like, in discrimination claims' (GB EE 24).

Apart from the lay judges' particular contribution of workplace knowledge and experience which, as noted above, is more salient in French and German labour courts than in British ones, the lay judges said that they contributed 'common sense' which is a general, not a context-specific competence. Indeed, that phrase was frequently mentioned by German lay judge interviewees 'A good bit of common sense and self-confidence is needed' (G EE DO 26); the fact 'that you're part of 
life' (G ER HAL 18); 'I think, it's experience of life and work that you can bring in... rather it's more common sense' (G EE MA 69); 'The basic requirement is common sense' (G EE DO 46).

Both British and German professional judges agreed that irrespective of the nature of their contribution, lay judges provided support for their view and/or acted as a sounding board: 'a surety for correctness' (G PJ HAL 16); 'it's useful sometimes just to have another person' (GB PJ 1).

Furthermore, lay judge interviewees in all the three countries recognised and accepted the primacy of the professional judge over matters of law. Indicative British lay judge comments included: 'Sometimes it's a point of law you know, and then we're in the hands of the [professional] judge because that's their area' (GB EE 38). 'You adapt, you adapt to the requirements of the law basically' (GB EE 31). 'We're not required to understand the law' (GB EE 23). 'Just because it's unfair doesn't make it unlawful' (GB EE 19). German lay judge interviewees made similar comments: 'There are laws, and decisions and judgments that I can't know as a lay judge but which are relevant' (G EE DO 45); 'It's the [professional] judge who has the decisive opinion and can then bring about agreement between us all' (G ER B 7).

Brandstätter et $\mathrm{al}^{36}$ made the point over 30 years ago that 'not arriving at a unanimous decision may be experienced by the [German professional judge] as a personal defeat' and a few British lay judge interviewees noted that some professional judges spent considerable time and effort seeking to influence lay judges in order to reach unanimity. This may have been given impetus by Lord Justice Mummery opining in the Court of Appeal that 'it is undesirable, on the whole, for tribunals to reach split decisions' ${ }^{37}$

On the other hand, the fact that so many decisions were unanimous in both German and British labour courts cannot simply be ascribed to professional judge dominance. Many lay judges said that having heard the evidence, most of the time the professional and lay judges would come to the same view. Typical comments from British interviewees included: 'we've automatically already

\footnotetext{
${ }^{36}$ Brandstätter et al, see note 26, p.155.

${ }^{37}$ Anglian Home Improvements Ltd v Kelly [2004] IRLR 793
} 
come to the same conclusion'; 'it's bloody obvious'; 'unless you have differential ears or something you're going to come up with something vaguely similar'; 'we would come to a similar decision'; 'three people with common sense viewing evidence...it wouldn't be surprising that they reached the same conclusion' (GB-EE-27/24/1/6/10). Similar comments came from German interviewees. For instance, one said: 'All three hear the same' (G EE HAL 9).

The position in France is very different to that in the other two countries. Where only the lay judges adjudicate, deliberations can resemble negotiations. 'There is an employee camp and an employer camp. Afterwards as it evolves of course, we find solutions based on understanding and agreement' (F EE13).

\section{Lay and professional judges' attitudes}

The findings reported above suggest that the professional judge, when in attendance, dominates in deliberations in France, but only in the cases where he/she presides as a tie-breaker, and in Great Britain where workplace knowledge is rarely material to the deliberations. However, this general finding should be qualified by the attitudes of both the lay and professional judges.

Looking first at the attitudes of the lay judges as seen by the British and German professional judges, some lay judges were seen as more participative and assertive than others, often because of their prior experience in the workplace. For instance, a German professional judge noted that 'Lay judges who are works councillors are more likely to step into discussion when the professional judge's view doesn't fit with their own.... possibly because they are used to discussing things at work' (G PJ DO 48), while another German professional judge (G PJ DO 29) commented in similar terms in respect of those who were/had been chairs of a works council. In fact, a survey ${ }^{38}$ of German lay judges found that one third of all responding German lay judges $(34.4 \%, n=2,391)$ were

${ }^{38}$ A. Höland and C. Buchwald unter Mitarbeit von E. Krausbeck, Ehrenamtliche Richterinnen und Richter in der Arbeits- und der Sozialgerichtsbarkeit. Eine empirische Untersuchung in Baden-Württemberg, Berlin und Sachsen-Anhalt, (Halle 2018). 
currently sitting on a works council (private sector) or a staff council (public sector) and another fifth $(21.3 \% n=1,635)$ had done so in the past.

In Great Britain, professional judges did not distinguish lay judges because of their workplace role but rather because of their approach. 'I think it depends on the [lay judge]. I think most of my colleagues agree that there are just one or two... who are passengers' (GB PJ 9). 'I sat with [lay judges] whose ability to analyse evidence forensically and spot something I've missed is humbling' (GB PJ 5).

Interestingly British lay judges, when assessing other British lay judges, echoed the views of British professional judges and noted variations. Thus, some said that others, but not themselves, did not wish to disagree with the professional judge. [They] 'don't want to upset people' (GB EE 40) 'I think it's quite hard for people to argue with the [professional] judge. I don't mind' (GB EE 10). Indeed, several British lay judges said that they were uncomfortable about being in a minority and as long as they had aired their views, they were willing to accede to the majority, a process that one professional judge described as 'crumbling' (GB PJ 7).

Turning to the attitudes of professional judges as seen by the lay judges, in general German lay judges said it varied as to how inclusive they were. 'It depends on the [professional judge] of course, but most... don't behave like schoolmasters... There are naturally exceptions, as always, but most [professional] judges treat it like a partnership' (G ER DO 45). 'It depends on how open the [professional] judge is' (G EE B (49); 'There are also [professional] judges who are very open. They'll listen' (G EE HAL).

In Great Britain, a minority of lay judges whom we interviewed said they were not treated as equals 'Good god, no. That's not even close.... It's not even in the same ballpark' (GB EE 19); 'there's a status issue here.... I'm the judge and you two are not' (GB EE 9); 'they treat us with sufferance mainly' (GB EE 11). Moreover, one British lay judge (GB EE 5) exceptionally, recounted an incident some 20 years ago, when a professional judge had actively sought to suppress dissent: bullying and threatening the lay judge in an attempt to secure a change of mind (in vain) and 
thereafter, not sitting with him again. Most British lay judges, however, were of the view that their relationship with British professional judges was one of equality.

Nevertheless, on further probing, the British lay judges, like their German counterparts, made distinctions between the professional judges. Some British lay judges distinguished between the older and younger professional judges. 'More recently the [professional] judges are more willing to engage a bit with [Us]' (GB EE 18); 'It's much easier to work with the new [professional] judges' (GB EE 34); 'old school can be a bit condescending' (GB EE 32). Other British lay judges distinguished not by age, but by the professional judge's attitude. 'Some [professional judges] see [lay judges] as a necessary evil.... and others are much more inclusive' (GB EE 18); 'there's some I find very good and very inclusive. There are others who aren't' (GB EE 9); 'some [professional] judges love having lay [judges] there.... And other [professional] judges think we're a complete waste of time' (GB EE 33); 'their behaviour is as varied as there are [professional] judges' (GB EE 13); 'we are treated as an inconvenience by some [professional] judges... [a] significant minority' (GB EE 11); 'they're all individuals so it varies' (GB ER 9); ‘some are very inclusive and some are less so' (GB ER 7).

In France (as in Germany and Great Britain) the lay judges we interviewed had a range of views about the professional judges. For instance, one said:

Professional judges generally treat us very well... We have studied differently but we are all people and equal. You know, for the [professional] judges, being on the labour court is a stage in their lives. ... They're going to do criminal law, and they do a lot of other things. They're not specialists like us. On some things, we know more than they do (F EE 03).

Many French lay judges, however, reported that professional judges dominated during tiebreak hearings and the ensuing deliberations. For example one said: 'Often what happens is that when they arrive, they've already made the decision. They've studied the file.... I don't have the impression that we have much influence in the discussion afterwards (F EE 13). Also, some French lay judges (especially those less confident of their legal knowledge) suggested that some professional judges looked down on them. For example, one said: 
One day, a legal representative used an aspect of the labour code in his plea and I opened the code to verify it. The [professional] judge said: 'Sir, it is not useful to open the code; my interpretation is the correct one'. I didn't answer. But I must say that I found it haughty and offensive (F EE 10).

Having presented and reviewed our findings, we now set them against the literature in order to draw some conclusions.

\section{DISCUSSION AND CONCLUSIONS}

This research has led us to reject Bourdieu's stark distinction between the lay and the legal, ${ }^{39}$ with the latter having mastery for several reasons. First, lay judges are not powerless. British lay judges, unlike their French and German counterparts, have some latent power vis-à-vis the British professional judge as their notes could prove decisive in a complaint of bias against a professional judge. Also, British and German lay judges have actual power in that they can outvote the professional judge, although this happens very rarely, while French lay judges have actual power too as they can exclude the professional judge from playing any part at all in adjudication. Second, Bourdieu's juridical field does not allow for lay judges who are inside the juridical field as non-legal participants. Third, lay judges' knowledge of workplace norms is not largely irrelevant in the decisions of French and German labour courts as they always sit on contested dismissals and can put themselves in the employer's shoes, unlike their British counterparts.

Status characteristics theory, in contrast to Bourdieu, is consistent with our findings. To recap, this theory posits that a person has a high status in a group if he/she is regarded by other group members as being the most useful contributor to the group's goals. We find that the professional judge has a higher status because his/her expertise is the most relevant to the provision of a labour court judgment based on legal norms; thus he/she has more prestige and power, will initiate more interaction and receive more attention and deference from the lay judges and exercise greater influence in the group especially when there are disagreements.

\footnotetext{
${ }^{39}$ See note 13 p.817.
} 
The role of the professional judge and their higher status in most situations, however, is tempered by the institutional provisions in the three countries. For instance, although in the labour courts in Germany and Great Britain the professional judge is always in the chair when a hearing takes place and thus primus inter pares, in France most labour court hearings take place without the professional judge being present and so the issue of professional judge influence does not arise in most cases.

Moreover, while professional judges have legal knowledge, the knowledge and experience of workplace norms by German and French lay judges will in many cases also help the group to accomplish its goals where the case concerns a contested dismissal. This is because in those two countries, the lay judges always sit on unfair dismissal cases and have to decide themselves whether the employer acted reasonably as noted above. In contrast, in Great Britain, as noted above, lay judges essentially only sit on unfair dismissal cases where a concurrent discrimination claim is brought and even then they may only review the employer's actions within a broad band; they do not decide themselves whether the employer acted reasonably. Furthermore, French and German professional judges, as career judges, normally have little or no workplace knowledge. This contrasts with their British counterparts who will usually have had many years of advising/acting for parties on an employment matter and, in so doing, have obtained knowledge of the norms of many workplaces, albeit indirectly. Accordingly, the French and German professional judge's status will be lower than that of the lay judges at least during a part of the deliberative process.

Fujita and Hotta ${ }^{40}$ and Machura ${ }^{41}$ found that lay participants could be at a disadvantage because of their informational disadvantage. In Germany, the professional judge will have had informational advantage in respect of the instant case. He/she will have chaired pre-hearing conciliation and seen case papers a considerable time in advance, while in France two of the four lay judges will normally have sought to conciliate and so will have learned about the main issues in

\footnotetext{
${ }^{40}$ See note 23.

${ }^{41}$ See note 21.
} 
the case already. This contrasts with Great Britain where a separate government body conciliates and the professional judge normally only receives the case papers immediately before the hearing.

Nevertheless, informational advantage did not appear to have any effect on status hierarchies. Thus even though German lay judges had less information than the German professional judge on the case, or conversely French lay judges had as much (or more) knowledge of the case than the professional judge, this had no bearing on our finding that German and French lay judges' workplace knowledge was often a significant factor in adjudication.

Professional judge influence, however, is not only determined by the institutional provisions; our research draws attention to a mediating factor: the attitudes of the lay and professional judges. Some lay judges were more prepared to challenge authority than others. Also, the attitudes of professional judges were seen to vary, with some being regarded by the lay judges as more inclusive than others. This chimes with Machura's ${ }^{42}$ findings that lay judges were active in deliberations where the professional judge treated them as equals

So we return to our research question: do professional judges dominate? The answer is not straightforward for the reasons outlined above, but we conclude that the professional judge does not always dominate. Instead, this article concludes that the professional judge has a significant degree of influence, but the extent of this influence is determined largely by the institutional context, particularly the fact that in some countries lay judges' workplace knowledge is much more important in the decision-making process in respect of contested dismissals than in others. Further institutional differences, which affect the power balance between professional and lay judges include the frequency of sitting and thus the accumulation of labour court experience, Significantly, some French lay judges, particularly those acting as presidents (chairs) of chambers, sit many times a week and indeed more often than the French professional judge, unlike their counterparts in Germany and Great Britain. 
Institutional differences, however, are mediated by the attitudes of the lay judges often stemming from their prior workplace experience and conditioned by their perceptions of the professional judges. Further research should be undertaken, however, to test whether our findings in respect of German, British and French $1^{\text {st }}$ instance labour courts apply to other 'mixed' labour courts.

We end with a warning. In British social security tribunals lay judges, like those in labour courts, have a particular, albeit non-legal expertise, but Wikely and Young found that the legalisation of the benefit system had made it more difficult for lay judges to contribute. ${ }^{43}$ We note that employment law has become more technical and complex over the last three decades and the more that it does so, the less will lay judges be able to make a significant contribution to labour court decision making.

${ }^{43}$ N. Wikely and R. Young 'The Marginalisation of Lay Members in Social Security Appeal Tribunals ', ,(1992) 14(2) Journal of Social Welfare and Family Law, 127-142. 
Table 1: Key differences between French German and British $1^{\text {st }}$ instance labour courts

\begin{tabular}{|c|c|c|c|}
\hline & France & Germany & Great Britain \\
\hline $\begin{array}{l}\text { Conciliation } \\
\text { prior to } \\
\text { hearing }\end{array}$ & $\begin{array}{l}\text { Two lay judges, who then } \\
\text { take part in any adjudication }\end{array}$ & $\begin{array}{l}\text { Professional judge, } \\
\text { who then takes part } \\
\text { in any adjudication }\end{array}$ & $\begin{array}{l}\text { Separate agency: Advisory, } \\
\text { Conciliation \& Arbitration } \\
\text { Service }\end{array}$ \\
\hline $\begin{array}{l}\text { Lay judge } \\
\text { appointment }\end{array}$ & $\begin{array}{l}\text { Until } 2018 \text { election by } \\
\text { employees from competing } \\
\text { union lists \& by employers } \\
\text { from employer lists. Now } \\
\text { nomination akin to } \\
\text { Germany. }\end{array}$ & $\begin{array}{l}\text { Nomination by } \\
\text { unions \& employer } \\
\text { associations. } \\
\text { Appointment by } \\
\text { regional authorities. }\end{array}$ & $\begin{array}{l}\text { Self-nomination; selection by } \\
\text { application form/sift/interview }\end{array}$ \\
\hline $\begin{array}{l}\text { Number of } \\
\text { lay judges } \\
\text { (2017) }\end{array}$ & 14,500 & $\begin{array}{l}24,269 \text { but this } \\
\text { covers both } 1^{\text {st }} \\
\text { AND } 2^{\text {nd }} \text { instance } \\
\text { labour courts }\end{array}$ & 997 \\
\hline $\begin{array}{l}\text { Professional } \\
\text { Judge }\end{array}$ & $\begin{array}{l}\text { Career judiciary mostly sits } \\
\text { in relevant District Court. }\end{array}$ & $\begin{array}{l}\text { Career judiciary } \\
\text { sits virtually full- } \\
\text { time in labour court }\end{array}$ & $\begin{array}{l}\text { Appointed only after working } \\
\text { for at least } 5 \text { years in a legal } \\
\text { activity. Most sit full-time. }\end{array}$ \\
\hline $\begin{array}{l}\text { Composition } \\
\text { of labour } \\
\text { court }\end{array}$ & $\begin{array}{l}4 \text { lay judges (bipartite) } \\
\text { Professional judge only if tie } \\
\text { at merits hearing. }\end{array}$ & $\begin{array}{l}\text { Professional judge } \\
+2 \text { lay judges } \\
\text { (tripartite) }\end{array}$ & $\begin{array}{l}\text { Professional judge }+2 \text { lay } \\
\text { judges (tripartite) essentially } \\
\text { only in discrimination cases. } \\
\text { Otherwise professional judge } \\
\text { sits alone }\end{array}$ \\
\hline $\begin{array}{l}\text { Training for } \\
\text { lay judges }\end{array}$ & $\begin{array}{l}\text { Allowance of } 6 \text { weeks } \\
\text { during } 5 \text {-year period of } \\
\text { office + initial joint training } \\
\text { at the Ecole Nationale de la } \\
\text { Magistrature. }\end{array}$ & $\begin{array}{l}\text { None required, but } \\
\text { some courts, } \\
\text { unions \& employer } \\
\text { associations } \\
\text { provide training. }\end{array}$ & $\begin{array}{l}\text { Before sitting }-2 \text { days } \\
\text { (observation \& lectures), Then } \\
1 \text { day per year (England \& } \\
\text { Wales), } 2 \text { days per year } \\
\text { (Scotland) }\end{array}$ \\
\hline $\begin{array}{l}\text { Length of } \\
\text { case where } \\
\text { lay judges } \\
\text { sit. }\end{array}$ & 4- 5 cases in half a day & $\begin{array}{l}4-5 \text { cases in half a } \\
\text { day }\end{array}$ & Half a day to over 20 days \\
\hline $\begin{array}{l}\text { The writing } \\
\text { of the } \\
\text { judgment }\end{array}$ & $\begin{array}{l}\text { Lay judge (unless tie-break } \\
\text { when professional judge } \\
\text { provides) }\end{array}$ & Professional judge & Professional judge \\
\hline
\end{tabular}

Source: P. Burgess, S. Corby, A. Höland, H. Michel, L. Willemez, C. Buchwald and E. Krausbeck, (2017) 'The Roles, Resources and Competencies of employee Lay Judges: a cross-national study of Germany, France and Great Britain, Working Paper 151, (Dusseldorf: Hans Böckler Stiftung 2017) https://www.boeckler.de/pdf/p fofoe WP 051 2017.pdf [accessed 9.1.18]. 